\title{
糖脂質修飾が決めるタンパク質の選別輸送機構 GPIアンカーの構造変化によるタンパク質輸送・膜局在の制御
}

タンパク質が正しく機能するためには，合成された後 に適切に選別され，目的地へ運ばれることが極めて重要 である.タンパク質の選別輸送や局在はどのように決め られ，調節されているのか. 多くのタンパク質は「輸 送・局在化シグナル」を有して扮り，これらのシグナル によって輸送経路や局在が規定されている．輸送・局在 化シグナルには, タンパク質上のペプチド配列や膜貫通 領域の長さ, ユビキチン化や脂質修飾, 糖鎖修飾のよう な翻訳後修飾などが知られている。ここではグリコシル ホスファチジルイノシトール（GPI）と呼ばれる糖脂質 によって修飾された一群のタンパク質（GPIアンカー型 タンパク質）の細胞内輸送について紹介したい.

GPIはホスファチジルイノシトールにグルコサミン， マンノース，エタノールアミンリン酸が結合した糖脂質 であり, 小胞体内腔でGPIアンカー付加シグナルをC末 端に有するタンパク質に付加される，GPIによるタンパ ク質への修飾は真核生物で広く保存された翻訳後修飾で あり, 出芽酵母では約 60 種類, 哺乳動物には 150 種類以 上のタンパク質がGPIアンカー型として存在する．GPI アンカー型タンパク質は小胞体で合成された後，ゴルジ 体を経て細胞膜（酵母ではさらに大部分が細胞壁）へ輸 送される. GPIアンカー型タンパク質の特徵的な性質と して，(1）「脂質ラフト」と呼ばれるスフィンゴ脂質や コレステロールからなる生体膜ドメインと会合するこ と,（2）上皮細胞のような多くの極性細胞で, 頂端（ア ピカル）側へ選択的に輸送されること，（3）エンドサイ トーシスされる際にクラスリンを必要としない経路に よって輸送されること，（4）出芽酵母では小胞体からゴ ルジ体へ輸送される際に, Gaplpや alpha-factorのよう な積荷タンパク質とは別の輸送小胞によって運ばれるこ と，などが示されている。このようにGPIアンカーは夕 ンパク質に特徴的な性質を付与し, 輸送や膜局在を決定 していると考えられる. 近年, 出芽酵母や動物細胞の解 析から GPIアンカーがタンパク質に付加された後, 輸送 過程において, その構造を変化させることがわかってき た.さらに, GPIアンカーの構造変化（リモデリング） が, 小胞体-ゴルジ体間の輸送, 脂質ラフトとの会合に 必要であることが明らかとなってきた.
動物細胞では，これまでに3つのGPIリモデリング反 応が行われることが知られている(1) (図1A)。まず, （1）小胞体においてタンパク質に修飾された後, GPIア ンカーのイノシトール環に付加された脂肪酸がPGAP1 により除去される (イノシトール脱アシル化)。つづい て（2）PGAP5により，GPIの2つ目のマンノースに結 合したエタノールアミンリン酸が除去される（糖鎖リモ デリング)。さらに（3）ゴルジ体でPGAP3 と PGAP2 によってPI部分の $s n-2$ 位の不飽和脂肪酸が飽和脂肪酸 に置換される(脂肪酸リモデリング)。出芽酵母では基 本的なりモデリング反応は保存されているものの, 動物 細胞とは反応場所や順序, 付加される脂肪酸の分子種が 異なっている（図1B)。また，多くのGPIアンカー型夕 ンパク質の脂質部分がジアシルグリセロール型からセラ ミド型へ変換される（セラミドリモデリング）. GPIア ンカーの構造変化のうち, 特に脂肪酸リモデリングは, GPIアンカー型タンパク質が脂質ラフト（生化学的には 低温で非イオン性界面活性剤に不溶画分 (DRM)) と会 合するのに必須の反応である.

一方, 動物細胞変異株の解析から, 小胞体で行われる PGAP1 とPGAP5による2つのリモデリング反応はGPI アンカー型タンパク質の小胞体-ゴルジ体間の効率的な 輸送に必要であり, GPIの構造自体が輸送シグナルとし て機能することが明らかとなった ${ }^{(2)}$. GPIアンカー型夕 ンパク質は分泌タンパク質と同様, 小胞体からゴルジ体 ヘコートタンパク質複合体II（COPII）小胞で輸送され る. PGAP1おょびPGAP5の変異細胞を用いて解析を 行ったところ，COPII小胞が形成される場所である，小 胞体出口部位（ERES）へのソーティングに異常があっ た．さらに，小胞体でリモデリングされた GPIアンカー を効率的に認識する分子として, p24ファミリータンパ ク質が同定された ${ }^{(3)}$. p24ファミリータンパク質は細胞 質側にCOPIIおよびCOPIタンパク質と直接結合するモ チーフを有するI型膜タンパク質であり，ファミリー間 でヘテロオリゴマーを形成し，小胞体-ゴルジ体間をリ サイクリングすることが知られている，以前より，出芽 酵母において 24 ファミリータンパク質である Emp $24 \mathrm{p}$, Erv25p, Erp1pがGPIアンカー型タンパク質 Gaslpの小 


\section{今日の話題}

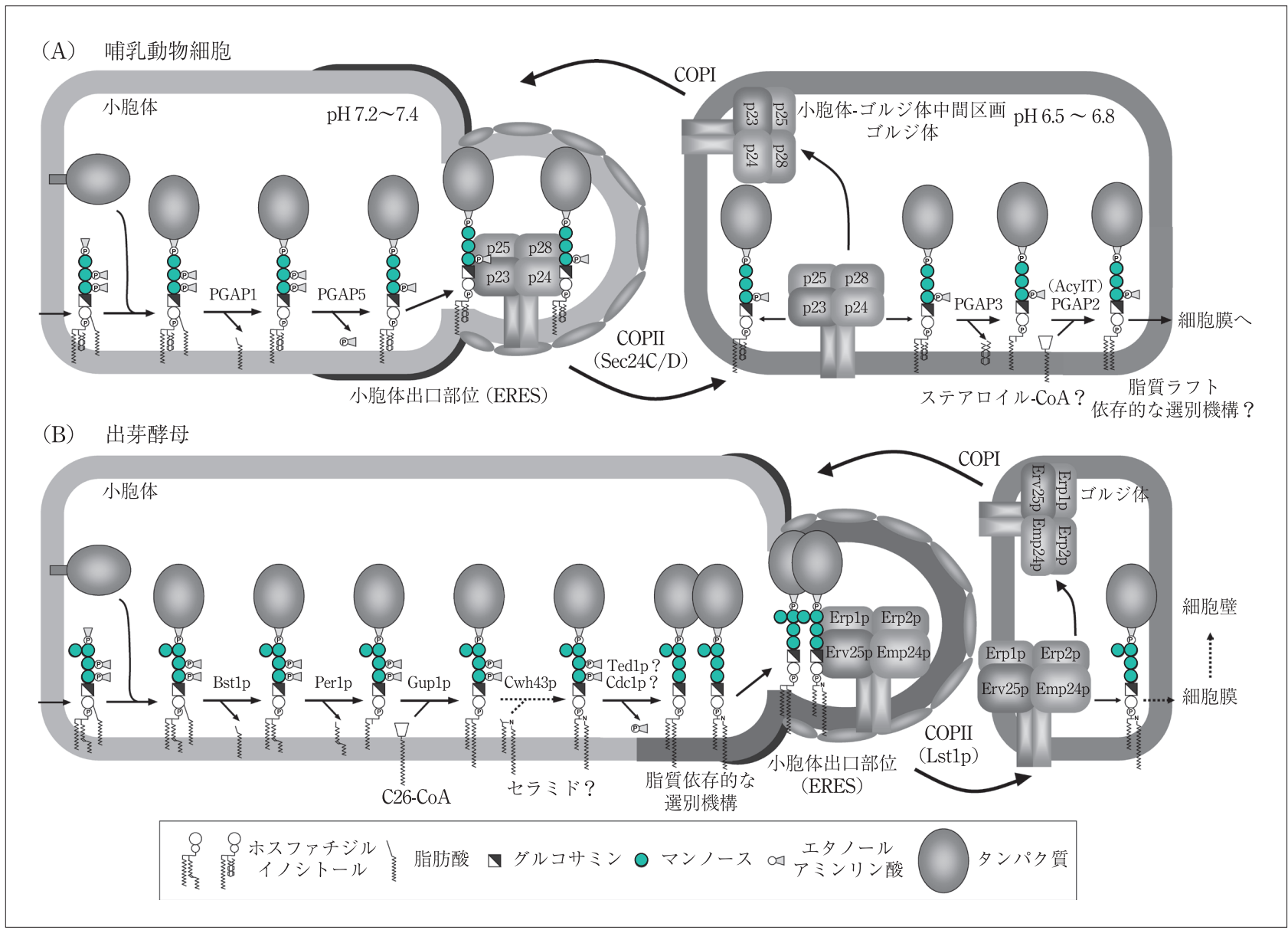

図1 - 哺乳動物細胞 (A) および出芽酵母 (B) における GPIアンカ一型タンパク質の構造変化と細胞内輸送 Elsevier（文献1）より許可を得て転載した。

胞体-ゴルジ体間の効率的な輸送に必要であることが報 告されている ${ }^{(4)}$. 動物細胞においても $\mathrm{p} 24$ 遺伝子のノッ クダウンにより，GPIアンカー型タンパク質のERESへ の濃縮が減少し，輸送が選択的に遅延した。p24ファミ リータンパク質とGPIアンカー型タンパク質との結合/ 解離は $\mathrm{pH}$ 依存的であり，小胞体 $(\mathrm{pH} 7.2 \sim 7.4)$ で結合 し，小胞体・ゴルジ体中間区画あるいはシスゴルジ体 （pH $6.5 ＼mathrm{~ 6.8 ） て ゙ 解 離 す る と 考 え ら れ る . こ れ ら の 結 果 ~}$ から，p24ファミリータンパク質は正しくリモデリング されたGPIアンカーを効率的に認識し，COPII小胞に濃 縮する積荷受容体であることが示唆された（図1).

GPIアンカー型タンパク質のERESへの集積は，動物 細胞ではp24タンパク質に依存しているのに対して，出 芽酵母では脂質依存的に行われ，p24ファミリータンパ ク質は集積されたGPIアンカー型タンパク質と COPIIを
結ぶアダプターとして働いているようだ ${ }^{(5)}$ 。この違いは 小胞体出口での GPIアンカー構造の違いによって起きて いる可能性がある。すなわち出芽酵母では脂肪酸リモデ リング，セラミドリモデリングが小胞体で行われるた め，脂質間相互作用に依存する選別機構が関与している と考えられる(図1B).

COPIIの構成因子のうち, Sec24 は輸送される積荷夕 ンパク質に直接結合し，積荷の選別を行っている．哺乳 動物には 4 つの Sec24のパラログ（Sec24A, B, C, D), 䤉 母では3つ（Sec24p, Sfb2p, Lst1p）が存在し，このうち 主にSec24C/D, Lst1pがp24ファミリータンパク質を認 識し，GPIアンカー型タンパク質の小胞体からの輸送に 働いているようである。COPIIの構成因子である Sec13p は生存に必須であるが，酵母の解析から GPI イ ノシトール脱アシル化遺伝子 BST1 あるいは $\mathrm{p} 24$ ファミ 


\section{今日の話題}

リー遺伝子EMP24, ERV25が欠損することにより， $\sec 13$ 破壊株が生存できること（bypass-of-sec-thirteen： BST）が知られている。興味深いことに最近，GPIリモ デリングに関与する他の遺伝子 (PER1, TED1, GUP1, $E R P 1, E R P 2) も B S T$ 遺伝子として機能することが示 された ${ }^{(6)}$.この理由として, 以下のような説明が考えら れる. Sec13pはCOPIIを強固にすることで輸送小胞膜 の湾曲能を増加させているが, Sec13pが久損すると GPIアンカー型タンパク質のような逆湾曲能の強い積荷 を含んだ輸送小胞が形成できなくなり，細胞は生存でき ない。一方，BST遺伝子の変異により GPIアンカーの リモデリング反応や積荷受容体に欠損が生じると，GPI アンカー型タンパク質が濃縮されないため, Sec13pの 欠損下でも輸送小胞が形成されるようになり, Sec13変 異の致死性が抑圧される。この結果からも GPIアンカー の構造変化がタンパク質の選別輸送シグナルとなってい ることを示している.

以上のようにGPIアンカーはその構造を変化させるこ とにより，修飾されたタンパク質の輸送や膜局在を制御
している.これはGPIの構造的物性とそれを作り出す醅 素，さらには変化した構造を認識する分子によって生み 出されている. 今後, さらなるリモデリング分子の同定 や改変酵素や認識分子の調節機構を解明することによ り，GPIアンカーによるタンパク質修飾の意義を明らか にすることが期待される.

1) M. Fujita \& T. Kinoshita:Biochim. Biophys. Acta, 1821, 1050 (2012).

2) M. Fujita, Y. Maeda, R. Moonjin, Y. Yamaguchi, R. Taguchi \& T. Kinoshita: Cell, 139, 352 (2009).

3) M. Fujita, R. Watanabe, N. Jaensch, M. Romanova-Michaelides, T. Satoh, M. Kato, H. Riezman, Y. Yamaguchi, Y. Maeda \& T. Kinoshita:J. Cell Biol., 194, 61 (2011).

4) M. Muniz, C. Nuoffer, H. Hauri \& H. Riezman:J. Cell Biol., 148, 925 (2000).

5) G. A. Castillon, A. Aguilera-Romero, J. Manzano-Lopez, S. Epstein, K. Kajiwara, K. Funato, R. Watanabe, H. Riezman \& M. Muniz : Mol. Biol. Cell, 22, 2924 (2011).

6) A. Copic, C. F. Latham, M. A. Horlbeck, J. G. D’Arcangelo \& E. A. Miller : Science, 335, 1359 (2012).

(藤田盛久, 大阪大学微生物病研究所免疫不全疾患研 究分野)

\section{プロフィル}

浅見忠男（Tadao Asami）＜略歴>1983 年東京大学農学部農芸化学科卒業 / 1988 年日本特殊農薬製造（現バイエルクロップ サイエンス) (株) $/ 1992$ 年理化学研究所 $/$ 2006 年東京大学大学院農学生命科学研究 科，現在に至る<研究テーマと抱負 $>$ 天 然・合成化合物を問わない植物成長制御物 質の発見・創製とその科学・実学への応用 <趣味>ラケット競技, 映画鑑賞, 読書

荒井 綜一 (Soichi Arai) <略歴>昭和 34 年東京大学農学部農芸化学科 /森永製
菓 (株), 東京大学農学部助手 - 助教授 - 教 授, 東京農業大学応用生物科学部教授を歴 任, 現在は同大学客員教授<研究テーマと 抱負>テーマは食品機能のゲノミクス. 抱 負は食品の機能性・栄養性・安全性・感性 の統合研究領域の構築＜趣味＞大リーグ野 球観戦, 宝塚観劇

磯 部 稔 (Minoru Isobe) Vol. 50, No. 7, p. 483 参照

大竹 久夫 (Hisao Ohtake) <略歴 $>$
1968 年東京大学工学部卒業 / 1973 年大阪 大学大学院工学研究科博士後期課程修了 (工博) $/ 1978$ 年東京大学応用微生物研究 所助教授 $/ 1990$ 年広島大学工学部醗酵工 学講座教授 $/ 2003$ 年大阪大学大学院工学 研究科応用生物工学専攻教授 $/ 2005$ 年同 研究科生命先端工学専攻教授 $/ 2008$ 年 ン資源リサイクル推進協議会会長，現在に 至る<研究テーマと抱負 $>$ リン資源枯渴の 問題に正面から取り組んでいきたい 